\title{
The association between human cytomegalovirus and glioblastomas: a review
}

\author{
Christian B. Hochhalter ${ }^{1}$, Christopher Carr ${ }^{1}$, Brannan E. O’Neill'1, Marcus L. Ware ${ }^{2}$, Michael J. Strong ${ }^{1}$ \\ ${ }^{I}$ Department of Neurological Surgery, Tulane University School of Medicine, New Orleans, LA 70112, USA. \\ ${ }^{2}$ Department of Neurological Surgery, Ochsner Clinic Foundation, New Orleans, LA 70112, USA.
}

Correspondence to: Dr. Michael J. Strong, Department of Neurological Surgery, Tulane University School of Medicine, New Orleans, LA 70112, USA. E-mail: mstrong@tulane.edu

How to cite this article: Hochhalter CB, Carr C, O’Neill BE, Ware ML, Strong MJ. The association between human cytomegalovirus and glioblastomas: a review. Neuroimmunol Neuroinflammation 2017;4:96-108.

Dr. Michael J. Strong recently graduated from the MD/PhD program at Tulane University School of Medicine in
New Orleans. He will be starting residency training in neurological surgery at the University of Michigan in Ann
Arbor. His dissertation project utilized next generation sequencing and bioinformatics to investigate oncogenic
pathogens. He has authored 30+ peer-reviewed publications. He has received numerous awards including the
Alpha Omega Alpha Student Research Fellowship, the Campagna Scholarship in Neurological Surgery, the
American Association of Neurological Surgeons Young Neurosurgeons Committee Mission Fellowship, and the
National Institutes of Health National Research Service Award F30 Predoctoral Fellowship.

Article history:

Received: 17-02-2017

Accepted: 23-05-2017

Published: 16-06-2017

Key words:

Human cytomegalovirus,

cytomegalovirus,

gliomas,

glioblastoma multiforme,

immunotherapy,

brain tumors,

next generation sequencing

\section{ABSTRACT}

Human cytomegalovirus (HCMV) was reported in glioblastoma multiforme (GBM) over a decade ago and this finding has the potential to increase our understanding of the disease and it offers an alternative tumor-specific therapeutic target. Due of this promise, there is a fair amount of time, energy and money being directed towards understanding and utilizing this connection for eventual therapeutic purposes. Nevertheless, the association between GBM and HCMV remains controversial. Several studies have reported conflicting results, further undermining the potential clinical value of this association. In this review, the authors will discuss the latest developments on this evolving issue. Specifically, the results of the latest studies, both positive and negative, will be discussed. Furthermore, potential theories to explain discrepancies reported in the literature will be proposed. Clinical implications including potential targets for anti-HCMV therapy and the latest developments in anti-HCMV therapy will be presented. Finally, solutions to remedy this controversial issue in neuro-oncology will be offered.

\section{INTRODUCTION}

Glioblastoma multiforme (GBM) is the most common malignant primary brain tumor in adults. An estimated 26,070 new cases of primary malignant brain and central nervous system (CNS) tumors are expected 
to be diagnosed in the United States in 2017. ${ }^{[1]}$ Nearly everyone diagnosed with GBM succumbs to the disease, which has a median survival of 12-15 months even with aggressive treatment. ${ }^{[2]}$ Despite years of research, there has been minimal improvement in the overall survival rate. Reports of human cytomegalovirus (HCMV) in GBM 15 years ago by Cobbs et al. ${ }^{[3]}$ raised hopes for potential viral targeted therapeutic options for this disease. Recently, anti-HCMV immunotherapy based clinical trials have been established to assess efficacy in treating this disease. At the basic research level, efforts are being made to investigate the oncogenic potential of individual HCMV genes to understand how HCMV might contribute to GBM. Despite these continuing efforts and the time lapsed since the discovery of HCMV in GBM, the association remains controversial. This review serves to highlight the latest developments in this association and its clinical validity as a therapeutic target for primary brain tumors.

\section{ENVIRONMENTAL ETIOLOGIES OF GBM}

Although several studies have investigated risk factors for brain tumors, our knowledge of their etiology is limited. The only clear environmental risk factor that has been identified for glial neoplasms is ionizing radiation. ${ }^{[4]}$ The relationship between viruses and the development of primary brain tumors is complex and unclear. While the majority of efforts have been focused on studying HCMV, other viruses such as polyomaviruses $\mathrm{JC}$ and $\mathrm{BK}$ have been implicated in brain tumors. ${ }^{[5,6]} \mathrm{JC}$ and BK viruses typically are asymptomatic infections that predominately present in immune suppressed individuals. Disease states from polyomavirus infections are broad and range from BK virus-related nephropathy ${ }^{[7]}$ to JC virusrelated progressive multifocal leukoencephalopathy. ${ }^{[8]}$ The propensity for the CNS characteristic of these viruses has led to attempts to develop better screening methods to clarify this relationship. ${ }^{[9]}$

\section{HCMV AND GBM ASSOCIATION}

Although an association between HCMV and GBM was first reported in 2002,, ${ }^{[3]}$ there is still a high degree of inconsistency in the literature regarding the detection of viral agents in CNS tumors. Further, the recent debate between Cinatl and Cobbs labs as to the presence of HCMV in GBM continues to fuel this ongoing controversy. ${ }^{[10-13]}$ The initial concept of oncomodulation was developed by Cinatl et al. ${ }^{[14]}$ in 1996. In their study, they proposed that HCMV could increase tumor malignancy by infecting tumor cells and affecting either directly or indirectly cofactors for tumor genesis. ${ }^{[14]}$ To determine whether HCMV was actually associated with GBM, they developed a standardized viral detection protocol. However, in a recent paper, Baumgarten et al. ${ }^{[10]}$ demonstrated negative results for HCMV in their GBM cohort despite demonstrating positive staining in their control samples. In a paper addressing this, Cobbs et al. ${ }^{[11]}$ stated that Baumgarten et al. ${ }^{[10]}$ did not use the carefully optimized protocol established in his lab, ${ }^{[15]}$ which is crucial to detect low level HCMV infection in GBM. In response, Cinatl et al. ${ }^{[12]}$ stated that in observing similar staining in their glioma samples from HCMV seropositive and seronegative patients, they reached out to the 3 groups reporting positive results. In one group, the data could not be reproduced. The other two groups agreed to stain samples from Cinatl's lab, however, found no difference in staining in the glioma samples observed between the HCMV seropositive and seronegative patients. Despite demonstrating negative results, this data was not available to publish. Moving forward, both groups agree that a standard protocol for detecting HCMV in GBM samples needs to be established and agreed upon.

Several hypotheses have been proposed to help explain discrepancies reported in the literature including geographic differences, differences in seropositivity, the use of different cohorts, and differences in protocols and experimental conditions used for traditional detection methods, such as polymerase chain reaction (PCR), in situ hybridization (ISH), and immunohistochemistry (IHC) assays, which can lead to differences in sensitivities for detecting low levels of viral gene expression.

Although differences in HCMV seropositivity have been investigated, there is currently no clear association between HCMV seropositivity and incidence of GBM. HCMV seroprevalance is lower in Whites than in Blacks and Hispanics; however, GBM incidence is higher ${ }^{[16]}$ Additionally, HCMV seroprevalance is higher in women than men, while the incidence of GBM is higher in men. ${ }^{[16]}$

As a way to consolidate the data regarding the detection of HCMV in CNS tumors, a symposium was convened in Washington, DC on April 17, 2011. At this symposium, oncologists and virologists studying this very relationship had the opportunity to discuss data addressing this topic. At the conclusion of this symposium, a summary paper was published reporting the consensus position in 4 major areas including the existence of HCMV in gliomas, the role of HCMV in gliomas, HCMV as a therapeutic target, and key future investigative directions. ${ }^{[17]}$ Based on 
the data presented at the symposium and discussions with experts at that time, it was concluded that HCMV sequences and viral gene expression exist in many high-grade gliomas and that in vitro studies suggest that HCMV can modulate key signaling cellular pathways in glioblastomas. ${ }^{[17]}$

Currently, HCMV is not considered to be a classic oncogenic virus because it has not been demonstrated to possess acute transforming activity. ${ }^{[18]}$ Instead, it is believed that HCMV contributes to GBM pathogenesis through oncomodulation of host cellular pathways. This notion of HCMV modulating host cellular pathways stems from evidence generated in other model systems. Specifically, studies performed in a mouse model have shown that persistent infection of endothelial cells by CMV, defined as the expression of viral genes without evidence of cytopathogenic effect on host cells, resulted in the production of inflammatory cytokines and renin, which led to the development of hypertension. ${ }^{[19]}$ Applying this evidence to GBM, one hypothesis proposes that persistent infection with HCMV could lead to production of inflammatory cytokines that may contribute to pathogenesis through disruption of the cell cycle. ${ }^{[17]}$

Of the estimated 173 open reading frames present in the HCMV genome ${ }^{[20]}$ only a few of the gene products, such as IE1, pp71, glycoprotein B, and US28, have been detected in GBMs. Forced expression of HCMV IE1 was shown to increase stemness properties (e.g. self-renewal) and proliferation of glioma stemlike cells in vivo. ${ }^{[21]}$ Follow-up studies demonstrated that IE1 promotes the tumor phenotype in these settings through inactivation of the p53 and Rb tumor suppressor proteins and through activation of the PI3-K/AKT signaling pathway. ${ }^{[22]}$ Long-term HCMV infected glioma cultures demonstrated upregulation of key signaling mediators such as SOX2, STAT3, BMX and IL-6. ${ }^{[23]}$ In addition, infection of GBM cells with HCMV led to upregulation of CD133 and other stem cell-like factors such as Notch1, Sox2, Oct4, and Nestin. ${ }^{[24]}$ HCMV infection of GBM cells has also led to tumor proliferation through an upregulation of a proteoglycan, endocan, which has been shown to be involved in several cellular processes including angiogenesis. ${ }^{[25]}$ Previously, overexpression of HCMV pp71 was shown to induce a pro-inflammatory response via activation of NFKB signaling in adult neural precursor cells. ${ }^{[26]} \mathrm{HCMV}$ glycoprotein B has been shown to mediate viral cellular entry via the receptor tyrosine kinase PDGFR-alpha resulting in activation of the PI3-K/AKT signaling pathway. ${ }^{[27]}$ Another key HCMV product that is implicated in GBM development is the chemokine receptor US28. HCMV
US28 regulates several cellular pathways including STAT3, VEGF, and e-NOS signaling which promotes GBM pathogenesis by regulating angiogenesis, invasion, and immune evasion. ${ }^{[28,29]}$ While these experiments show that these viral genes have the potential to be oncogenic, the question as to whether $\mathrm{HCMV}$ is association with GBM remains unclear.

The current line of thinking in the association between HCMV and GBM revolves around four potential hypotheses. ${ }^{[30]}$ The first is that HCMV is causal; however, there is no evidence to date to support this concept in humans. The best evidence we have at this time for HCMV causing GBMs is in a mouse model. ${ }^{[31]}$ Researchers at Brigham and Women's Hospital developed a mouse CMV-infected GBM mouse model using mut3 mice, which spontaneously develop grade III and IV astrocytomas. They demonstrated that MCMV-infected mut3 mice had decreased overall survival compared to naive mut3 mice. ${ }^{[31]}$ The second hypothesis is that HCMV may be oncomodulatory, thereby enhancing tumor progression by a specific mechanism or a combination of mechanisms, which were detailed in the previous section. ${ }^{[17,18,20,22-24,26-29,32,33]}$ The third hypothesis is that HCMV may be a bystander with little effect on tumor growth, and the HCMV antigens are expressed because of the highly immunosuppressive tumor microenvironment observed in GBM. There is no direct evidence to date to support this concept. The last hypothesis is that these observations are merely an experimental artifact. Several recent publications have outlined possible scenarios where detection of HCMV may be due to experimental artifact including cross-reactivity of antibodies, ${ }^{[34]}$ the concentration of antibodies, ${ }^{[35]}$ or presence of expression vector genetic material in sequencing datasets. ${ }^{[36]}$

\section{HCMV DETECTION IN GBM}

Several studies have investigated the association between HCMV and GBM in an attempt to resolve this controversial issue. Various detection approaches have been utilized by several investigators including traditional techniques (e.g. PCR, ISH, and IHC) and next generation sequencing (NGS) technology in an attempt to detect the presence of HCMV in GBM cells [Table 1].

The most recent studies that have reported a positive association utilized traditional detection methods. One study looked for the presence of HCMV antigens pp65 or IE1-72 in 25 pediatric GBM patients. The study showed a $66.7 \%$ detection rate in the samples for either pp65 or IE $1-72{ }^{[58]}$ The authors of this study also 
Table 1: Studies evaluating presence of HCMV in gliomas

\begin{tabular}{|c|c|c|c|}
\hline Authors & Number of samples analyzed & Detection method & Analyte \\
\hline Cobbs et al.., 2002 & $\begin{array}{l}27 / 27 \text { gliomas FFPE } \\
10 / 10 \text { gliomas }\end{array}$ & $\begin{array}{l}\text { IHC for IE1-72, pp65, p52 } \\
\text { ISH biotinylated oligonucleotide probe } \\
\text { specific for HCMV early gene mRNA } \\
\text { ISH digoxigenin-labeled HCMV total } \\
\text { genome DNA probe } \\
\text { Nested PCR for gB (UL55) } \\
\text { EM-IHC anti-pp65 mAb and gold particles }\end{array}$ & $\begin{array}{c}\text { DNA } \\
\text { Viral particles }\end{array}$ \\
\hline Lau et al., ${ }^{[37]} 2005$ & $\begin{array}{l}\text { 0/17 gliomas FFPE } \\
\text { 0/2 ODG FFPE } \\
\text { 0/3 ependymomas FFPE } \\
\text { 0/17 gliomas FFPE } \\
\text { 0/2 ODG FFPE } \\
\text { 0/3 ependymomas FFPE } \\
\text { 0/17 gliomas FFPE } \\
\text { 0/2 ODG FFPE } \\
\text { 0/3 ependymomas FFPE }\end{array}$ & $\begin{array}{l}\text { ISH digoxigenin-labeled probe specific for } \\
\text { HCMV early gene mRNA } \\
\text { ISH digoxigenin-labeled probe specific for } \\
\text { HCMV DNA (pp65 and pp150) } \\
\text { PCR for gB (UL55) }\end{array}$ & RNA, DNA \\
\hline Sabatier et al., ${ }^{[38]} 2005$ & $\begin{array}{l}\text { 9/116 CNS tumors ( } 15 \\
\text { ependymomas, } 81 \text { GBM, } 20 \text { ODG) } \\
\text { TMA } \\
1 / 25 \text { gliomas fresh frozen }\end{array}$ & $\begin{array}{l}\text { IHC for IE1, p52 } \\
\text { ISH biotinylated HCMV DNA probe }\end{array}$ & DNA, Protein \\
\hline Poltermann et al., ${ }^{[39]} 2006$ & $\begin{array}{l}\text { 0/73 CNS tumors ( } 38 \text { gliomas, } 29 \\
\text { meningiomas, } 6 \text { ACNs) FFPE } \\
0 / 77 \text { ( } 40 \text { gliomas, } 31 \text { meningiomas, } \\
6 \text { ACNs) }\end{array}$ & $\begin{array}{l}\text { IHC for IE, EA, pp65 } \\
\text { Nested PCR for IE1 and gB (UL55) }\end{array}$ & Protein \\
\hline Mitchell et al.. ${ }^{[40]} 2008$ & $\begin{array}{l}\text { 16/17 GBM primary cultures } \\
21 / 34 \text { GBMs fresh frozen } \\
13 / 17 \text { GBM primary cultures }\end{array}$ & $\begin{array}{l}\text { IHC for IE1-72 } \\
\text { IHC for pp } 65 \\
\text { ISH FITC-conjugated 40-mer probes for } \\
\text { HCVM IE1 } \\
\text { ISH biotinylated HCMV total genome DNA } \\
\text { probe } \\
\text { IHC for IE1, pp65 gB, and pp28 } \\
\text { PCR for gB (UL55) }\end{array}$ & $\begin{array}{l}\text { Protein } \\
\text { DNA }\end{array}$ \\
\hline Scheurer et al.. ${ }^{[41]} 2008$ & $\begin{array}{l}\text { 21/21 GBM FFPE } \\
\text { 9/12 AA FFPE } \\
\text { 14/17 LGG FFPE }\end{array}$ & $\begin{array}{l}\text { IHC for IE1-72 and ISH fluorescein-labeled } \\
\text { oligonucleotide total HCMV genome DNA } \\
\text { probe mixture }\end{array}$ & Protein, DNA \\
\hline Slinger et al., ${ }^{[29]} 2010$ & 20/21 gliomas FFPE & IHC for IEA, US28 & Protein \\
\hline Lucas et al.. ${ }^{[42]} 2011$ & $\begin{array}{l}\text { 25/49 GBMs FFPE } \\
8 / 49 \text { GBMs FFPE }\end{array}$ & $\begin{array}{l}\text { IHC for pp65 } \\
\text { IHC for IE1 }\end{array}$ & Protein \\
\hline Ranganathan et al., ${ }^{[43]} 2012$ & $\begin{array}{l}\text { 75/75 GBM FFPE } \\
\text { 12/12 GBM fresh frozen }\end{array}$ & $\begin{array}{l}\text { PCR using } 12 \mathrm{HCMV} \text { primer pairs } \\
\text { PCR using } 19 \mathrm{HCMV} \text { primer pairs }\end{array}$ & DNA \\
\hline Rahbar et al.. ${ }^{[4]} 2012$ & $\begin{array}{l}\text { 79/80 GBMs FFPE } \\
76 / 80 \text { GBMs FFPE } \\
6 / 6 \text { selected GBM FFPE }\end{array}$ & $\begin{array}{l}\text { IHC for IEA } \\
\text { IHC for LA } \\
\text { ISH HCMV-DNA total genome fluorescein } \\
\text { labeled probes }\end{array}$ & $\begin{array}{l}\text { Protein } \\
\text { DNA }\end{array}$ \\
\hline Bhattacharjee et al., ${ }^{[4]} 2012$ & $\begin{array}{l}16 / 17 \text { gliomas fresh frozen } \\
9 / 12 \text { gliomas fresh frozen }\end{array}$ & $\begin{array}{l}\text { Nested PCR for IE } \\
\text { WB for pp } 65, \text { IE1-72, gB }\end{array}$ & $\begin{array}{l}\text { DNA } \\
\text { Protein }\end{array}$ \\
\hline Fonseca et al., ${ }^{[46]} 2012$ & $27 / 75$ gliomas fresh frozen & PCR for pp65 & DNA \\
\hline Khoury et al., ${ }^{[47]} 2013$ & $\begin{array}{l}\text { 0/168 GBMs } \\
\text { 0/47 LGGs }\end{array}$ & RNA-seq & RNA \\
\hline Tang et al.., ${ }^{[48]} 2013$ & 0/167 GBMs & RNA-seq & RNA \\
\hline \multirow[t]{2}{*}{ Rahbar et al.. ${ }^{[49]} 2013$} & $\begin{array}{l}\text { 74/75 GBMs FFPE } \\
\text { 70/75 GBMs FFPE }\end{array}$ & $\begin{array}{l}\text { IHC for IEA } \\
\text { IHC for LA }\end{array}$ & Protein \\
\hline & $\begin{array}{l}\text { 19/19 selected GBM FFPE } \\
5 / 5 \text { GBM primary cultures }\end{array}$ & $\begin{array}{l}\text { ISH CMV DNA probe } \\
\text { PCR for IE }\end{array}$ & $\begin{array}{l}\text { DNA } \\
\text { DNA }\end{array}$ \\
\hline Ding et al., ${ }^{[50]} 2014$ & $\begin{array}{l}51 / 67 \text { gliomas FFPE } \\
44 / 67 \text { gliomas FFPE } \\
35 / 67 \text { gliomas }\end{array}$ & $\begin{array}{l}\text { IHC for IE1-72 } \\
\text { IHC for pp } 65 \\
\text { Nested PCR for gB (UL55) }\end{array}$ & $\begin{array}{l}\text { Protein } \\
\text { DNA }\end{array}$ \\
\hline Dos Santos et al., ${ }^{[51]} 2014$ & $\begin{array}{l}21 / 22 \text { GBMs fresh frozen } \\
20 / 22 \text { GBMs fresh frozen }\end{array}$ & $\begin{array}{l}\text { PCR for pp } 65 \\
\text { hemi-nested PCR for gB (UL55) }\end{array}$ & DNA \\
\hline Cimino et al., ${ }^{[52]} 2014$ & 0/21 gliomas & $\begin{array}{l}\text { Unmapped reads from targeted cancer } \\
\text { gene panel }\end{array}$ & DNA \\
\hline
\end{tabular}




\begin{tabular}{|c|c|c|c|}
\hline Authors & Number of samples analyzed & Detection method & Analyte \\
\hline \multirow[t]{2}{*}{ Cosset et al., ${ }^{[53]} 2014$} & 0/20 GBMs & $\begin{array}{l}\text { Semi-qPCR for CMV } \\
\text { Nested PCR for gB }\end{array}$ & RNA, DNA \\
\hline & 0/5 GBMs & RNA-seq & RNA \\
\hline \multirow[t]{7}{*}{ Yamashita et al., ${ }^{[34]} 2014$} & $\begin{array}{l}\text { 0/59 GBMs ( } 40 \text { fresh-frozen and } 19 \\
\text { FFPE) }\end{array}$ & PCR for gB and IE1 & DNA \\
\hline & $\begin{array}{l}0 \text { (confirmed)/5 GBMs (false- } \\
\text { positive staining on WB confirmed } \\
\text { by LC/MS/MS analysis) }\end{array}$ & WB for IE1/2 and pp28 & Protein \\
\hline & 10/10 GBMs & $\mathrm{IHC}$ for pp28 & Protein \\
\hline & $7 / 10$ GBMs & $\mathrm{IHC}$ for IE $1 / 2$ & \\
\hline & 5/10 GBMs & $\mathrm{IHC}$ for $\mathrm{pp} 65$ & \\
\hline & 0/10 GBMs & IHC for UL44 & \\
\hline & 0/10 GBMs & FISH HCMV BAC DNA & DNA \\
\hline Solomon et al.. ${ }^{[54]} 2014$ & 0/68 GBM TMA & IHC for HCMV cocktail & Protein \\
\hline Baumgarten et al.. ${ }^{[10]} 2014$ & $\begin{array}{l}\text { 0/91 GBMs FFPE } \\
0 / 10 \mathrm{GBMs}\end{array}$ & $\begin{array}{l}\text { IHC for p52, pp } 65, \text { IEA } \\
\text { PCR for HCMV loci }\end{array}$ & $\begin{array}{l}\text { Protein } \\
\text { DNA }\end{array}$ \\
\hline Libard et al.., ${ }^{[55]} 2014$ & $\begin{array}{l}363 / 417 \text { extra- and intra-axial brain } \\
\text { tumors ( } 61 / 68 \text { GBMs) TMA }\end{array}$ & IHC for pp65 & Protein \\
\hline Ahani et al.. ${ }^{[56]} 2014$ & $\begin{array}{l}\text { 0/8 non-glioma tumor tissue } \\
0 / 2 \mathrm{PA} \\
1 / 3 \mathrm{AA} \\
4 / 7 \mathrm{OA} \\
12 / 16 \mathrm{GBMs}\end{array}$ & PCR (HCMV detection kit) & DNA \\
\hline Tang et al., ${ }^{[57]} 2015$ & $0 / 34 \mathrm{GBM}$ & WGS & DNA \\
\hline \multirow{3}{*}{ Wakefiled et al., ${ }^{[58]} 2015$} & $14 / 24$ peds GBMs & IHC for IE1-72 & DNA, Protein \\
\hline & $12 / 24$ peds GBMs & IHC for pp65 & \\
\hline & $13 / 16$ peds GBMs & ISH for HCMV DNA probe cocktail & \\
\hline \multirow[t]{2}{*}{ Bianchi et al., ${ }^{[59]} 2015$} & $\begin{array}{l}\text { 30/43 GBMs fresh frozen } \\
8 / 14 \text { ODG }\end{array}$ & IF for IE1 and LA & Protein \\
\hline & $\begin{array}{l}\text { 17/20 meningiomas } \\
2 / 6 \text { IE1 IF-positive GBMs } \\
17 / 34 \text { GBMs } \\
\text { 5/14 ODG } \\
6 / 13 \text { meningiomas }\end{array}$ & $\begin{array}{l}\text { IHC for IE1 } \\
\text { Nested PCR for gB }\end{array}$ & $\begin{array}{l}\text { Protein } \\
\text { DNA }\end{array}$ \\
\hline \multirow{5}{*}{ Shamran et al., ${ }^{[60]} 2015$} & 33/36 GBM FFPE & IHC for IE1-72 & DNA, Protein \\
\hline & 28/36 GBM FFPE & $\mathrm{IHC}$ for pp65 & \\
\hline & 26/36 GBM FFPE & IHC for LA & \\
\hline & 10/10 selected GBM samples & Nested PCR for IE1 & \\
\hline & 0/30 meningioma FFPE & $\mathrm{IHC}$ for IE1-72, pp65, and late antigen & \\
\hline \multirow[t]{4}{*}{ Holdhoff et al., ${ }^{[35]} 2016$} & $\begin{array}{l}\text { 0/25 GBMs fresh-frozen } \\
\text { 0/70 HGG TMA }\end{array}$ & $\begin{array}{l}\text { qPCR for US17 } \\
\text { IHC for pp } 65\end{array}$ & $\begin{array}{l}\text { DNA, RNA, } \\
\text { Protein }\end{array}$ \\
\hline & 0/20 GBMs FFPE & $\mathrm{IHC}$ and $\mathrm{CISH}$ for IE1/2 and pp65 & \\
\hline & $\begin{array}{l}\text { 3/18 HCMV DNA plasma samples } \\
\text { 8/15 serum HCMV laG }\end{array}$ & & \\
\hline & 0/18 GBMs FFPE & $\mathrm{IHC}, \mathrm{CISH}, \mathrm{PCR}$ & \\
\hline \multirow[t]{8}{*}{ Strong et al., ${ }^{[36]} 2016$} & 0/157 GBM & RNA-seq datasets & RNA \\
\hline & 0/13 recurrent GBM & & \\
\hline & 0/514 LGGs & & \\
\hline & 0/17 recurrent LGGs & & \\
\hline & $\begin{array}{l}\text { 0/92 MRI-guided GBM biopsies } \\
\text { 0/9 qlioma stem-like cell cultures }\end{array}$ & & \\
\hline & 0/51 GBM & WGS datasets & DNA \\
\hline & $0 / 10$ recurrent GBM & & \\
\hline & 0/64 meningioma & ddPCR for HCMY IU 55 & \\
\hline \multirow{3}{*}{ Lin et al., ${ }^{[61]} 2016$} & $\begin{array}{l}0 / 6 \text { GBM fresh frozen } \\
\text { 0/19 }\end{array}$ & ddPCR for HCMV UL55 & DNA \\
\hline & $\begin{array}{l}\text { 4/19 GBM FFPE, 0/20 GBM OCT, } \\
\text { 0/6 GBM fresh frozen }\end{array}$ & ddPCR for EBV LMP1 & \\
\hline & 3/19 GBM FFPE, 3/20 GBM OCT, & ddPCD for HUV 1157 & \\
\hline Taha et al., ${ }^{[62]} 2016$ & $0 / 32$ GBMs & IHC for HCMV and PCR for UL34, UL80.5 & DNA Protein \\
\hline \multirow{3}{*}{ Stangherlin et al., ${ }^{[63]} 2016$} & 38/52 GBMs & PCR for UL83 & DNA, Protein \\
\hline & 30/52 GBMs & $\mathrm{IHC}$ for HCMV nuclear protein & \\
\hline & 19/52 GBMs & ISH for early 2.7 RNA & \\
\hline \multirow[t]{2}{*}{ Xing et al., ${ }^{[25]} 2016$} & $52 / 79$ glioma & IHC for pp65 & DNA, Protein \\
\hline & $43 / 79$ glioma & ISH for pp65 DNA & \\
\hline
\end{tabular}

FFPE: formalin-fixed paraffin-embedded; IHC: immunohistochemistry; ISH: in situ hybridization; HCMV: human cytomegalovirus; PCR: polymerase chain reaction; GBM: glioblastoma multiforme; EM: electron microscopy; ODG: oligodendroglioma; CNS: central nervous system; TMA: tissue microarray; ACN: acoustic neuromas; AA: anaplastic astrocytoma; LGG: low-grade glioma; WB: western blot; LA: HCMV late antigen; FISH: fluorescence in situ hybridization; IF: immunofluorescence; PA: pilocystic astrocytoma; OA: oligoastrocytoma; WGS: whole genome sequencing; CISH: chromogenic in situ hybridization; ddPCR: digital droplet PCR; OCT: optimal cutting temperature; HGG: high-grade glioma; IEA: immediate-early antigen 
performed ISH using a HCMV DNA probe cocktail and found that $81 \%$ of samples analyzed demonstrated HCMV specific staining. ${ }^{[58]}$ Another study utilized multiple detection assays to test for the presence of HCMV. The targets for these assays were IE1-72, pp65, and late antigen. A total of 36 formalin-fixed paraffinembedded (FFPE) GBM samples were tested across each assay with varying rates of detection. A total of 33 out of the 36 samples (91.6\%) stained positive for IE1-72. The other two HCMV antigens, pp65 and late antigen, stained positive in $28 / 36(77.7 \%)$ and $26 / 36$ $(72.2 \%)$, respectively. ${ }^{[60]}$

On the other hand, several recent studies have reported no association between HCMV and GBM. One study utilized several approaches including a prospective and retrospective analysis to detect the presence of HCMV in tissue, plasma, and serum of high-grade glioma (HGG) patients. ${ }^{[35]}$ The authors of this study retrospectively analyzed 25 fresh frozen tissues from GBM patients using PCR, tissue microarrays from $70 \mathrm{HGG}$ patients using $\mathrm{IHC}$, and 20 FFPE GBM tissues using IHC and $\mathrm{CISH}$ targeted at IE1/2 and pp65. All tissue analyzed for the presence of HCMV were found to be negative irrespective of method used. ${ }^{[35]}$ The prospective arm of the study contained 18 patients with newly diagnosed HGG. From these patients, a total of 11 FFPE whole sections, 38 plasma samples, and 15 serum samples were analyzed. Tissue samples were analyzed for HCMV using real-time PCR, $\mathrm{CISH}$, and $\mathrm{IHC}$ under the same protocols as the retrospective arm. Utilizing these different detection methods there was no evidence of HCMV in the 11 FFPE samples. Eight of 15 patients were seropositive for HCMV. Of the 38 plasma samples that were collected HCMV was detected in low levels in 3 samples at baseline and only one in follow up. ${ }^{[35]}$

Another study took a comprehensive approach to analyze a wide variety of samples using NGS to detect the presence of viral genomes in the samples. ${ }^{[36]}$ This analysis was performed through the publically available sequencing datasets from the Cancer Genome Atlas (TCGA). The samples tested included 157 RNA-seq datasets from primary GBM, 13 recurrent GBM, 514 low-grade gliomas, 17 recurrent low-grade gliomas, and 5 normal brain, and whole genome sequencing (WGS) datasets from 51 primary GBM, 10 recurrent GBM, and 20 normal matched blood samples. In addition, 92 RNA-seq datasets from MRI-guided biopsies and 9 glioma stem-like cell cultures were analyzed. Finally, 64 DNA-seq datasets from 11 meningiomas and their corresponding blood control samples were also analyzed. The authors of this study reported no strong evidence of HCMV in any of the samples. A few samples were found to contain low levels of viral reads but upon closer inspection the authors report that these reads likely represented artifact or non-pathological infections. Finally, evidence of human papillomavirus (HPV) and hepatitis B were found in a few LGG samples, however, the authors of this study state that these findings need further evidence to substantiate this association. ${ }^{[36]}$

Lastly, another study used droplet digital PCR (ddPCR) to detect the presence of HCMV, human herpes virus 6 (HHV-6), and Epstein-Barr virus (EBV) in brain tissue samples. ${ }^{\left[{ }^{[1]}\right.} \mathrm{A}$ total of 112 brain tissue samples comprising 45 glioblastoma, 12 astrocytoma grade III, 2 astrocytoma grade II, 4 astrocytoma grade $\mathrm{I}$, and 49 controls were included in this study. The study reported that neither HCMV nor HHV-6A was detected in any of the astrocytoma samples. A higher frequency of positivity was observed for EBV and HHV-6B compared to controls. ${ }^{[61]}$

A few recent studies may shed light onto why there is such discrepancy observed in the literature. A study by Yamashita et al. ${ }^{[34]}$ attempted to detect HCMV in GBM samples through a wide range of detection methods. They were unable to detect the presence of HCMV in many of the samples. Interestingly, the authors noted that the HCMV positivity demonstrated in a few samples were actually the HCMV antibodies binding to non-viral human proteins such as human albumin and myelin basic protein. ${ }^{[34]}$ This finding suggests a previously unknown cross-reactivity among HCMV antibodies. Another study by Holdhoff et al. ${ }^{[35]}$ assessed whether altering experimental conditions could generate false positive results. The authors of this study demonstrated positive staining in previously negative control fibroblast cells by using higher concentrations of the primary HCMV monoclonal antibody. Similarly, varying antibody concentrations in brain tumor FFPE samples demonstrated false positive staining. Taken together, the authors of this study suggest that false positive staining can be readily achieved simply by using high antibody concentrations even with antibodies that are designed to be specific. ${ }^{[35]}$

\section{THERAPEUTIC TARGETS FOR HCMV}

The potential for novel breakthroughs in treating patients with GBM has led to a search for HCMV specific targets. Currently, there are two main approaches that are being pursued; one focuses on anti-viral therapy and the other focuses on HCMV directed immunotherapy. 
The main approach to anti-viral therapy revolves around the use of valganciclovir ${ }^{[64-68]}$ and GTPases. ${ }^{[69]}$ The rationale for using valganciclovir stems from the hypothesis that it will suppress HCMV replication in HCMV-positive GBM cells leading to the suppression of virus-mediated tumor promoting mechanisms. Recently, researchers at Vanderbilt University investigated the use of combination therapy using bevacizumab and valganciclovir in treating recurrent GBM, which demonstrated a trend toward improved survival in those patients. ${ }^{[67]}$ Finally, valganciclovir may target other viruses besides HCMV, which have unclear roles in tumorigenesis. Despite these advantages, valganciclovir suppresses viral replication, but does not eradicate the virus. Therefore, short-term treatment of valganciclovir would not be ideal in treating glioma patients as the benefits of tumor suppression only last during treatment, necessitating long-term treatment to maintain the suppressive effects. Further, this therapy would not be suitable for GBMs where there is no HCMV present as the tumor cells would not be targeted.

The investigation of Rho GTPases and their contribution to tumor progression is another area that is under investigation as a potential treatment option. ${ }^{[69]}$ The rho GTPase family is known to play a crucial role in cytoskeleton organization, cell movement, and division. Three proteins within this family that are frequently altered in tumors include RhoA \& RhoC, which are typically overexpressed, while RhoB is usually downregulated. ${ }^{[70-72]}$ Using a naive GBM cell line, a GBM cell line that stably expresses HCMV IE1, and shRNA technology to knockdown the Rho GTPases, it was determined that HCMV infection and Rho isoform states affect cell morphology and influence proliferation rate and motility of human GBM cells. ${ }^{[69]}$

The other approach to treating HCMV associated GBM involves the use of HCMV directed immunotherapy. The idea of HCMV in GBM has led to potential immunotherapy targets for treatment of GBM. ${ }^{[73,74]} \mathrm{A}$ study conducted by Nair et al. ${ }^{[75]}$ evaluated whether $T$ cells stimulated by HCMV pp65 RNA-transfected dendritic cells target and eliminate GBM tumor cells. The authors of this study concluded that HCMVspecific $T$ cells can effectively target GBM tumor cells and their results support the rationale for the development of HCMV-directed immunotherapy in patients with GBM. ${ }^{[75]}$ As a result of this association and the potential therapeutic options, several groups are exploring novel approaches to developing GBMdirected immunotherapy and vaccines. ${ }^{[74]}$ Potential HCMV proteins that are being investigated for the development of immunotherapy targets include immediate early 1 (IE1), phosphoprotein 65 (pp65), and glycoprotein $\mathrm{B}(\mathrm{gB}) \cdot^{[74]}$

\section{CLINICAL IMPLICATIONS}

HCMV is a ubiquitous virus infecting nearly the entire world population. With all the attention aimed at targeting HCMV in GBM cells, the validity of HCMV as a clinical target is being explored. As of February 2017, there are 13 clinical trials being conducted in the United States evaluating anti-HCMV therapy for GBM patients registered on clinicaltrials.gov [Table 2]. Of these studies, two were terminated because of poor patient accrual. The first was a study sponsored by Penn State University entitled, "A Phase I-II study of allogeneic CMV specific cytotoxic $T$ lymphocytes (CTL) for patients with refractory glioblastoma multiforme (GBM). ${ }^{[76] " ~ T h e ~ g o a l ~ o f ~ t h i s ~ s t u d y ~ w a s ~ t o ~}$ evaluate the safety and efficacy of the administration of partially matched, allogenic HCMV specific cytotoxic T cells for patients with GBM who failed primary therapy. The other study entitled, "Phase I/II administration of CMV (cytomegalovirus)-specific cytotoxic $T$ cells in patients with glioblastoma multiforme (COGLI)" was sponsored by Baylor College of Medicine. ${ }^{[77]}$ The goal of this study was to determine the maximum tolerated dose of HCMV-specific T cells administered in combination with temozolomide (TMZ) in patients with newly diagnosed GBM. Additional goals of this study included identifying potential side effects and assessing the efficacy of this therapy for the treatment of GBM. Additionally, one study sponsored by the University of Florida entitled, "Peptide targets for glioblastoma against novel cytomegalovirus antigens," was withdrawn prior to enrollment of participants by the principal investigator. ${ }^{[78]}$ The goal of this study was to identify the optimal and safe HCMV peptide specific vaccine regimen in combination with $T M Z$ for patients with newly diagnosed GBM.

There are 8 studies currently active and/or recruiting patients. A phase I clinical trial sponsored by Baylor College of Medicine entitled "Administration of HER2 chimeric antigen receptor expressing CMVspecific cytotoxic $T$ cells in patients with glioblastoma multiforme (HERT-GBM)" is being conducted to determine the largest safe dose of HER2-CD28 CMV-T cells, to identify the potential side effects of this therapy, and to evaluate its efficacy. ${ }^{[84]}$ As of September 2016, this study is listed as ongoing but not recruiting participants. Another phase I/II clinical trial entitled "A Phase I/II clinical trial of autologous cytomegalovirus (CMV)-specific cytotoxic $T$ cells for glioblastoma (GBM) patients" is being sponsored by 
Table 2: Clinical trials evaluating anti-human cytomegalovirus therapy

\begin{tabular}{|c|c|c|c|}
\hline Studies [ClinicalTrials.gov Identifier] & Sponsor & Status & Completion date \\
\hline $\begin{array}{l}\text { Autologous CMV-specific cytotoxic T cells for GBM } \\
\text { patients [NCT02661282] }]^{79]}\end{array}$ & M.D. Anderson Cancer Center & $\begin{array}{l}\text { Currently recruiting } \\
\text { participants }\end{array}$ & $2020^{* *}$ \\
\hline $\begin{array}{l}\text { Vaccine therapy for the treatment of newly } \\
\text { diagnosed GBM (ATTAC-II) [NCT02465268] }{ }^{[80]}\end{array}$ & University of Florida & $\begin{array}{l}\text { Currently recruiting } \\
\text { participants }\end{array}$ & $2024^{* *}$ \\
\hline $\begin{array}{l}\text { Peptide targets for glioblastoma against novel } \\
\text { cytomegalovirus antigens (PERFORMANCE) } \\
\text { [NCT02864368] }]^{[81]}\end{array}$ & Duke University Medical Center & $\begin{array}{l}\text { Currently recruiting } \\
\text { participants }\end{array}$ & $2018^{\star *}$ \\
\hline $\begin{array}{l}\text { DC migration study for newly-diagnosed GBM } \\
\text { (ELEVATE) [NCT02366728] }]^{82]}\end{array}$ & Duke University Medical Center & $\begin{array}{l}\text { Currently recruiting } \\
\text { participants }\end{array}$ & $2020^{* *}$ \\
\hline $\begin{array}{l}\text { Nivolumab with DC vaccines for recurrent brain } \\
\text { tumors (AVERT) [NCT02529072] }{ }^{[83]}\end{array}$ & Duke University Medical Center & $\begin{array}{l}\text { Currently recruiting } \\
\text { participants }\end{array}$ & $2019^{* *}$ \\
\hline $\begin{array}{l}\text { CMV-specific cytotoxic T lymphocytes expressing } \\
\text { CAR targeting HER2 in patients with GBM (HERT- } \\
\text { GBM) [NCT01109095] }]^{[84]}\end{array}$ & Baylor College of Medicine & $\begin{array}{l}\text { Ongoing, but not } \\
\text { recruiting participants }\end{array}$ & $2028^{* *}$ \\
\hline 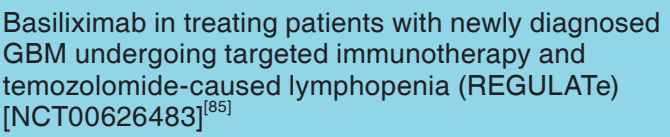 & Duke University Medical Center & $\begin{array}{l}\text { Ongoing, but not } \\
\text { recruiting participants }\end{array}$ & $2018^{\star *}$ \\
\hline $\begin{array}{l}\text { Vaccine therapy in treating patients with newly } \\
\text { diagnosed GBM (ATTAC) [NCT00639639] }]^{[86]}\end{array}$ & Duke University Medical Center & $\begin{array}{l}\text { Ongoing, but not } \\
\text { recruiting participants }\end{array}$ & $2018^{* *}$ \\
\hline $\begin{array}{l}\text { Evaluation of recovery from drug-induced } \\
\text { lymphopenia using cytomegalovirus-specific T-cell } \\
\text { adoptive transfer (ERaDICATe) [NCT00693095] }]^{[87]}\end{array}$ & Duke University Medical Center & Completed & 2015 \\
\hline $\begin{array}{l}\text { Peptide vaccine for glioblastoma against } \\
\text { cytomegalovirus antigens (PERFORMANCE) } \\
\text { [NCT01854099] }\end{array}$ & University of Florida & Withdrawn & 2014 \\
\hline $\begin{array}{l}\text { Efficacy and safety of Valcyte } ₫ \text { as an add-on } \\
\text { therapy in patients with malignant glioblastoma and } \\
\text { CMV infection [NCT00400322] }{ }^{[88]}\end{array}$ & Karolinska University Hospital & Unknown* & \\
\hline 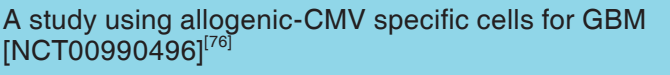 & Penn State University & Terminated & 2011 \\
\hline $\begin{array}{l}\text { Administration of CMV-specific cytotoxic T cells in } \\
\text { patients with GBM (COGLI) [NCT01205334] }{ }^{[77]}\end{array}$ & Baylor College of Medicine & Terminated & 2012 \\
\hline
\end{tabular}

*Results of this study have been published in the International Journal of Cancer ${ }^{[65]}{ }^{* *}$ estimated completion date; CMV: cytomegalovirus; GBM: glioblastoma multiforme; DC: dendritic cell

M.D. Anderson Cancer Center and as of January 2017 is recruiting participants. ${ }^{[79]}$ The goals of this combined Phase I/II study is to determine the highest tolerable dose of HCMV cytotoxic T lymphocytes (CTLs) that can be administered in combination with $T M Z$ to patients with GBM. The goal of the phase II component of this study is to identify if HCMV CTLs, when combined with TMZ, is effective in controlling GBM and whether this combination is safe for patients. There is a phase II clinical trial being sponsored by the University of Florida entitled "A Phase II randomized, blinded, and placebo-controlled trial of CMV RNA-pulsed dendritic cells with tetanus-diphtheria toxoid vaccine in patients with newly-diagnosed glioblastoma" that is currently recruiting participants as of January 2017. ${ }^{[80]}$ The goal of this study is to evaluate whether administration of HCMV pp65-dendritic cells is effective, as defined by a change in mean overall survival of GBM patients, if given in conjunction with stronger routine chemotherapy.

Several Phase I and II clinical trials are being sponsored by Duke University Medical Center. One study, entitled "Peptide targets for glioblastoma against novel cytomegalovirus antigens", is currently recruiting participants as of December 2016. ${ }^{[81]}$ The purpose of this phase I clinical trial is to determine side effects related to the peptide-CMV vaccine and assess the safety of a combination approach using the peptide-CMV vaccine and TMZ in patients with newly diagnosed GBM who underwent a complete or partial surgical resection. In addition, another goal of this study is to identify the $T M Z$ regimen schedule that yields the highest number of $T$ cells secreting interferon-gamma in response to the peptide-CMV vaccine. Another study, entitled "Evaluation of overcoming limited migration and enhancing cytomegalovirus-specific dendritic cell vaccines with adjuvant TEtanus pre-conditioning in patients with newly-diagnosed glioblastoma", is also currently recruiting participants as of June $2016 .{ }^{[82]}$ This phase II clinical trial will determine the impact of preconditioning with Tetanus-Diphtheria (Td) toxoid on human CMV pp65-lysosomal-associated membrane protein (LAMP) mRNA-pulsed autologous dendritic cells (DCs). This study will also assess the impact of pre-conditioning with $\mathrm{Td}$ toxoid and/or basiliximab 
on overall survival. A phase I clinical trial entitled "AVeRT: Anti-PD-1 monoclonal antibody (Nivolumab) in combination with $\mathrm{DC}$ vaccines for the treatment of recurrent Grade III and Grade IV brain tumors" is being conducted to assess the safety of giving DC vaccines with nivolumab, an anti-PD-1 monoclonal antibody, to patients with high grade gliomas. ${ }^{[83]}$ Overall survival and progression-free survival will also be evaluated. This study is currently recruiting participants as of December 2016. Two additional studies sponsored by Duke University Medical Center are both ongoing but are not currently recruiting participants as of July 2016. One of these studies, entitled "Regulatory T-cell inhibition with Basiliximab (Simulect ${ }^{\circledR}$ ) during recovery from therapeutic temozolomide-induced lymphopenia during antitumor immunotherapy targeted against cytomegalovirus in patients with newly-diagnosed glioblastoma multiforme", is a phase I clinical trial and will evaluate whether basiliximab, a monoclonal antibody to the IL-2 receptor of $\mathrm{T}$ cells. In addition, the study in determine whether basiliximab inhibits the functionality and numeric recovery of T-regulatory cells in GBM patients with TMZ-induced lymphopenia who are undergoing targeted immunotherapy using CMV pp65-LAMP mRNA-loaded dendritic cells and GM-CSF. ${ }^{[85]}$ The other study from Duke is also a phase I clinical trial. The study entitled "Anti-tumor immunotherapy targeted against cytomegalovirus in patients with newly-diagnosed glioblastoma multiforme during recovery from therapeutic temozolomide-induced lymphopenia" is to determine the feasibility and safety of vaccinating with HCMV pp65-LAMP mRNA-loaded dendritic cells, with or without autologous lymphocyte transfer, in patients with newly diagnosed GBM who previously had TMZinduced lymphopenia. ${ }^{[86]}$

A few additional studies investigating the use of HCMV as a novel target for GBM therapy have recently been completed. The phase I clinical trial entitled "Evaluation of recovery from drug-induced lymphopenia using cytomegalovirus-specific T-cell adoptive transfer" sponsored by Duke University Medical Center is listed as completed on clinicaltrials.gov. ${ }^{[87]}$ In this study, the investigators assessed if administering HCMVspecific DCs to adult patients with newly diagnosed GBM with TMZ-induced lymphopenia enhanced the T-cell response and whether this therapy was safe for patients. Another study entitled "A randomized double blind controlled proof of concept study of the efficacy and safety of Valcyte ${ }^{\circledR}$ as an add-on therapy in patients with malignant glioblastoma with successful surgical resection of at least $90 \%$ of the initial tumor and CMV infection demonstrated histologically and immunohistochemically," was sponsored by
Karolinska University Hospital in Sweden and has a current status that is listed as "unknown". ${ }^{[88]}$ Despite the status on clinicaltrials.gov, results from this study have been published in the International Journal of Cancer and will be presented in more detail below.

While we await the results of these studies, there have been two published clinical trials reporting differences in clinical efficacy. The first study was conducted by Stragliotto et al ${ }^{[65]}$ in Sweden and consisted of 42 patients randomized $1: 1$ to valganciclovir or placebo in addition to standard therapy. The primary endpoint of the study was tumor volume at 3 and 6 months assessed by neuroimaging. Secondary endpoints included progression free survival and overall survival at $6,12,18$, and 24 months. Authors of this study concluded that valganciclovir is safe and well tolerated in patients receiving both temozolomide and radiation therapy. However, primary and secondary endpoints were similar between the two groups, with trends but no significant differences observed. Despite demonstrating no significant differences, the authors, in a retrospective analysis of the same cohort with inclusion of additional patients on valganciclovir for compassionate reasons, found that the rate of survival of valganciclovir treated patients at 2 years was $62 \%$ compared to $18 \%$ in historical controls with similar demographics. ${ }^{[64]}$ The interpretation of this data has called into question whether the quoted survival rate is misleading. ${ }^{[89]}$

Another study conducted by Mitchell et al. ${ }^{[90]}$ at Duke University consisted of 12 patients randomized to pretreatment with mature dendritic cells (DC) or tetanus toxoid (Td), to help stimulate the immune system, with HCMV-specific dendritic cell vaccine in addition to standard therapy. The main objective of this study was not to test the validity of HCMV as a tumor specific target since the authors have previous shown the presence of HCMV antigens in GBM. As such, the authors surmise that HCMV is a viable target for immunotherapy. Therefore, the authors of this study wanted to evaluate methods for enhancing the efficacy of HCMV-specific dendritic cell vaccines. In so doing, six patients were pretreated with mature dendritic cells, while the other 6 patients were pretreated with tetanus toxoid. Primary endpoint was DC accumulation and migration. Secondary endpoints included progression free and overall survival. The authors demonstrated that there was greater DC migration in Td-pretreated patients than in those treated with mature DCs. Also, Td-pretreated patients showed a significant increase in both progression-free survival and overall survival compared to DC-pretreated patients. The authors concluded that pre-conditioning with $\mathrm{Td}$ may 
represent a viable strategy to improve anti-tumor immunotherapy. ${ }^{[0]}$

\section{CONCLUSION}

The notion as to how HCMV is associated with GBM is still unclear as there are discrepancies in the detection of HCMV. Theories as to why there are differences observed have been postulated and include the potential cross reactivity of HCMV antibodies used in traditional detection methods in addition to the variety of experimental conditions used. In light of the continued inconsistencies and ongoing debate, a standard detection protocol likely implementing multiple detection methods needs to be developed and interrogated in multiple institutions in order to remedy this controversial issue. Until this major endeavor is undertaken, the medical and scientific communities should be cognizant of this controversy. Although there is relative low risk in some of the experimental treatments discussed (e.g. valganciclovir), physicians and scientists should exercise caution when using anti-HCMV therapy until we have an updated consensus as to whether HCMV is associated with GBM.

\section{Authors' contributions}

Concept: C.B. Hochhalter, M.L. Ware, M.J. Strong

Design: C.B. Hochhalter, M.L. Ware, M.J. Strong

Literature search: C.B. Hochhalter, M.J. Strong

Data Analysis: C.B. Hochhalter, C. Carr, B.E. O'Neill, M.L. Ware, M.J. Strong

Manuscript preparation: C.B. Hochhalter, M.L. Ware, M.J. Strong

Manuscript editing: C.B. Hochhalter, C. Carr, B.E. O'Neill, M.L. Ware, M.J. Strong

Manuscript review: C.B. Hochhalter, C. Carr, B.E. O'Neill, M.L. Ware, M.J. Strong

\section{Financial support and sponsorship}

This work was supported by a Ruth L. Kirschstein National Research Service Award F30CA177267 from the National Cancer Institute to M.J. Strong.

\section{Conflicts of interest}

There are no conflicts of interest.

Patient consent

No patients were involved.

\section{Ethics approval \\ Not applicable.}

\section{REFERENCES}

1. Ostrom QT, Gittleman H, Xu J, Kromer C, Wolinsky Y, Kruchko C,
Barnholtz-Sloan JS. CBTRUS statistical report: primary brain and other central nervous system tumors diagnosed in the United States in 2009-2013. Neuro Oncol 2016;18:v1-75.

2. Wen PY, Kesari S. Malignant gliomas in adults. $N$ Engl $J$ Med 2008;359:492-507.

3. Cobbs CS, Harkins L, Samanta M, Gillespie GY, Bharara S, King PH, Nabors LB, Cobbs CG, Britt WJ. Human cytomegalovirus infection and expression in human malignant glioma. Cancer Res 2002;62:3347-50.

4. Fisher JL, Schwartzbaum JA, Wrensch M, Berger MS. Evaluation of epidemiologic evidence for primary adult brain tumor risk factors using evidence-based medicine. Prog Neurol Surg 2006;19:54-79.

5. Wrensch M, Minn Y, Chew T, Bondy M, Berger MS. Epidemiology of primary brain tumors: current concepts and review of the literature. Neuro Oncol 2002;4:278-99.

6. Saddawi-Konefka R, Crawford JR. Chronic viral infection and primary central nervous system malignancy. $J$ Neuroimmune Pharmacol 2010;5:387-403.

7. Sawinski D, Goral S. BK virus infection: an update on diagnosis and treatment. Nephrol Dial Transplant 2015;30:209-17.

8. Ferenczy MW, Marshall LJ, Nelson CD, Atwood WJ, Nath A, Khalili $\mathrm{K}$, Major EO. Molecular biology, epidemiology, and pathogenesis of progressive multifocal leukoencephalopathy, the JC virus-induced demyelinating disease of the human brain. Clin Microbiol Rev 2012;25:471-506.

9. Toptan T, Yousem SA, Ho J, Matsushima Y, Stabile LP, FernándezFigueras MT, Bhargava R, Ryo A, Moore PS, Chang Y. Survey for human polyomaviruses in cancer. JCI Insight 2016;1: pii: e85562.

10. Baumgarten P, Michaelis M, Rothweiler F, Starzetz T, Rabenau HF, Berger A, Jennewein L, Braczynski AK, Franz K, Seifert V, Steinbach JP, Allwinn R, Mittelbronn M, Cinatl J Jr. Human cytomegalovirus infection in tumor cells of the nervous system is not detectable with standardized pathologico-virological diagnostics. Neuro Oncol 2014;16:1469-77.

11. Cobbs C. Response to "human cytomegalovirus infection in tumor cells of the nervous system is not detectable with standardized pathologico-virological diagnostics". Neuro Oncol 2014;16:1435-6.

12. Michaelis M, Mittelbronn M, Cinatl J Jr. Towards an unbiased, collaborative effort to reach evidence about the presence of human cytomegalovirus in glioblastoma (and other tumors). Neuro Oncol 2015;17:1039.

13. Cobbs C. Reply to: towards an unbiased, collaborative effort to reach evidence about the presence of human cytomegalovirus in glioblastoma (and other tumors). Neuro Oncol 2015;17:1040.

14. Cinatl J Jr, Cinatl J, Vogel JU, Rabenau H, Kornhuber B, Doerr HW. Modulatory effects of human cytomegalovirus infection on malignant properties of cancer cells. Intervirology 1996;39:259-69.

15. Cobbs CS, Matlaf L, Harkins LE. Methods for the Detection of Cytomegalovirus in Glioblastoma Cells and Tissues. In: Yurochko $\mathrm{AD}$, Miller WE, editors. Human Cytomegaloviruses: Methods and Protocols. Totowa, NJ: Humana Press; 2014. p. 165-96.

16. Lehrer S, Green S, Ramanathan L, Rosenzweig K, Labombardi V. No consistent relationship of glioblastoma incidence and cytomegalovirus seropositivity in whites, blacks, and Hispanics. Anticancer Res 2012;32:1113-5.

17. Dziurzynski K1, Chang SM, Heimberger AB, Kalejta RF, McGregor Dallas SR, Smit M, Soroceanu L, Cobbs CS; HCMV and Gliomas Symposium. Consensus on the role of human cytomegalovirus in glioblastoma. Neuro Oncol 2012;14:246-55.

18. Cobbs C. Evolving evidence implicates cytomegalovirus as a promoter of malignant glioma pathogenesis. Herpesviridae 2011;2:10.

19. Cheng J, Ke Q, Jin Z, Wang H, Kocher O, Morgan JP, Zhang J, Crumpacker CS. Cytomegalovirus infection causes an increase of 
arterial blood pressure. PLoS Pathog 2009;5:e1000427.

20. Murphy E, Shenk T. Human cytomegalovirus genome. Curr Top Microbiol Immunol 2008;325:1-19.

21. Soroceanu L, Matlaf L, Khan S, Akhavan A, Singer E, Bezrookove V, Decker S, Ghanny S, Hadaczek P, Bengtsson H, Ohlfest J, LucianiTorres MG, Harkins L, Perry A, Guo H, Soteropoulos P, Cobbs CS. Cytomegalovirus immediate-early proteins promote stemness properties in glioblastoma. Cancer Res 2015;75:3065-76.

22. Cobbs CS, Soroceanu L, Denham S, Zhang W, Kraus MH. Modulation of oncogenic phenotype in human glioma cells by cytomegalovirus IE1-mediated mitogenicity. Cancer Res 2008;68:724-30.

23. Fiallos E, Judkins J, Matlaf L, Prichard M, Dittmer D, Cobbs C, Soroceanu L. Human cytomegalovirus gene expression in long-term infected glioma stem cells. PLoS One 2014;9:e116178.

24. Fornara O, Bartek J Jr, Rahbar A, Odeberg J, Khan Z, Peredo I, Hamerlik P, Bartek J, Stragliotto G, Landázuri N, Söderberg-Nauclér C. Cytomegalovirus infection induces a stem cell phenotype in human primary glioblastoma cells: prognostic significance and biological impact. Cell Death Differ 2016;23:261-9.

25. Xing Y, Wang Y, Wang S, Wang X, Fan D, Zhou D, An J. Human cytomegalovirus infection contributes to glioma disease progression via upregulating endocan expression. Transl Res 2016;177:113-26.

26. Matlaf LA, Harkins LE, Bezrookove V, Cobbs CS, Soroceanu L. Cytomegalovirus pp71 protein is expressed in human glioblastoma and promotes pro-angiogenic signaling by activation of stem cell factor. PLoS One 2013;8:e68176.

27. Cobbs C, Khan S, Matlaf L, McAllister S, Zider A, Yount G, Rahlin K, Harkins L, Bezrookove V, Singer E, Soroceanu L. HCMV glycoprotein B is expressed in primary glioblastomas and enhances growth and invasiveness via PDGFR-alpha activation. Oncotarget 2014;5:1091-100.

28. Soroceanu L, Matlaf L, Bezrookove V, Harkins L, Martinez R, Greene M, Soteropoulos P, Cobbs CS. Human cytomegalovirus US28 found in glioblastoma promotes an invasive and angiogenic phenotype. Cancer Res 2011;71:6643-53.

29. Slinger E, Maussang D, Schreiber A, Siderius M, Rahbar A, FraileRamos A, Lira SA, Söderberg-Nauclér C, Smit MJ. HCMV-encoded chemokine receptor US28 mediates proliferative signaling through the IL-6-STAT3 axis. Sci Signal 2010;3:ra58.

30. Lawler SE. Cytomegalovirus and glioblastoma; controversies and opportunities. J Neurooncol 2015;123:465-71.

31. Price RL, Chiocca EA. Modeling cytomegalovirus infection in mouse tumor models. Front Oncol 2015;5:61.

32. Joseph GP, McDermott R, Baryshnikova MA, Cobbs CS, Ulasov IV. Cytomegalovirus as an oncomodulatory agent in the progression of glioma. Cancer Lett 2017;384:79-85.

33. Soroceanu L, Cobbs CS. Is HCMV a tumor promoter? Virus Res 2011;157:193-203.

34. Yamashita Y, Ito Y, Isomura H, Takemura N, Okamoto A, Motomura K, Tsujiuchi T, Natsume A, Wakabayashi T, Toyokuni S, Tsurumi T. Lack of presence of the human cytomegalovirus in human glioblastoma. Mod Pathol 2014;27:922-9.

35. Holdhoff M, Guner G, Rodriguez FJ, Hicks JL, Zheng Q, Forman MS, Ye X, Grossman SA, Meeker AK, Heaphy CM, Eberhart CG, De Marzo $\mathrm{AM}$, Arav-Boger R. Absence of cytomegalovirus in glioblastoma and other high-grade gliomas by real-time PCR, immunohistochemistry and in situ hybridization. Clin Cancer Res 2016; doi: 10.1158/10780432.CCR-16-1490

36. Strong MJ, Blanchard E 4th, Lin Z, Morris CA, Baddoo M, Taylor $\mathrm{CM}$, Ware ML, Flemington EK. A comprehensive next generation sequencing-based virome assessment in brain tissue suggests no major virus -- tumor association. Acta Neuropathol Commun 2016;4:71.

37. Lau SK, Chen YY, Chen WG, Diamond DJ, Mamelak AN, Zaia JA,
Weiss LM. Lack of association of cytomegalovirus with human brain tumors. Mod Pathol 2005;18:838-43.

38. Sabatier J, Uro-Coste E, Pommepuy I, Labrousse F, Allart S, Trémoulet $\mathrm{M}$, Delisle MB, Brousset P. Detection of human cytomegalovirus genome and gene products in central nervous system tumours. $\mathrm{Br} J$ Cancer 2005;92:747-50.

39. Poltermann S, Schlehofer B, Steindorf K, Schnitzler P, Geletneky $\mathrm{K}$, Schlehofer JR. Lack of association of herpesviruses with brain tumors. J Neurovirol 2006;12:90-9.

40. Mitchell DA, Xie W, Schmittling R, Learn C, Friedman A, McLendon RE, Sampson JH. Sensitive detection of human cytomegalovirus in tumors and peripheral blood of patients diagnosed with glioblastoma. Neuro Oncol 2008;10:10-8.

41. Scheurer ME, Bondy ML, Aldape KD, Albrecht T, El-Zein R. Detection of human cytomegalovirus in different histological types of gliomas. Acta Neuropathol 2008;116:79-86.

42. Lucas KG, Bao L, Bruggeman R, Dunham K, Specht C. The detection of CMV pp65 and IE1 in glioblastoma multiforme. $J$ Neurooncol 2011;103:231-8

43. Ranganathan P, Clark PA, Kuo JS, Salamat MS, Kalejta RF. Significant association of multiple human cytomegalovirus genomic Loci with glioblastoma multiforme samples. J Virol 2012;86:854-64.

44. Rahbar A, Stragliotto G, Orrego A, Peredo I, Taher C, Willems J, Söderberg-Naucler C. Low levels of human cytomegalovirus infection in glioblastoma multiforme associates with patient survival; a casecontrol study. Herpesviridae 2012;3:3.

45. Bhattacharjee B, Renzette N, Kowalik TF. Genetic analysis of cytomegalovirus in malignant gliomas. J Virol 2012;86:6815-24.

46. Fonseca RF, Kawamura MT, Oliveira JA, Teixeira A, Alves G, Carvalho Mda G. The prevalence of human cytomegalovirus DNA in gliomas of Brazilian patients. Mem Inst Oswaldo Cruz 2012;107:953-4.

47. Khoury JD, Tannir NM, Williams MD, Chen Y, Yao H, Zhang J, Thompson EJ; TCGA Network, Meric-Bernstam F, Medeiros LJ, Weinstein JN, Su X. Landscape of DNA virus associations across human malignant cancers: analysis of 3,775 cases using RNA-Seq. $J$ Virol 2013;87:8916-26.

48. Tang KW, Alaei-Mahabadi B, Samuelsson T, Lindh M, Larsson E. The landscape of viral expression and host gene fusion and adaptation in human cancer. Nat Commun 2013;4:2513.

49. Rahbar A, Orrego A, Peredo I, Dzabic M, Wolmer-Solberg N, Strååt K, Stragliotto G, Söderberg-Nauclér C. Human cytomegalovirus infection levels in glioblastoma multiforme are of prognostic value for survival. J Clin Virol 2013;57:36-42.

50. Ding D, Han S, Wang Z, Guo Z, Wu A. Does the existence of HCMV components predict poor prognosis in glioma? J Neurooncol 2014;116:515-22.

51. dos Santos CJ, Stangherlin LM, Figueiredo EG, Corrêa C, Teixeira MJ, da Silva MC. High prevalence of HCMV and viral load in tumor tissues and peripheral blood of glioblastoma multiforme patients. $J$ Med Virol 2014;86:1953-61.

52. Cimino PJ, Zhao G, Wang D, Sehn JK, Lewis JS Jr, Duncavage EJ. Detection of viral pathogens in high grade gliomas from unmapped next-generation sequencing data. Exp Mol Pathol 2014;96:310-5.

53. Cosset É, Petty TJ, Dutoit V, Cordey S, Padioleau I, Otten-Hernandez $\mathrm{P}$, Farinelli L, Kaiser L, Bruyère-Cerdan P, Tirefort D, Amar ElDusouqui S, Nayernia Z, Krause KH, Zdobnov EM, Dietrich PY, Rigal E, Preynat-Seauve O. Comprehensive metagenomic analysis of glioblastoma reveals absence of known virus despite antiviral-like type I interferon gene response. Int J Cancer 2014;135:1381-9.

54. Solomon IH, Ramkissoon SH, Milner DA Jr, Folkerth RD. Cytomegalovirus and glioblastoma: a review of evidence for their association and indications for testing and treatment. $J$ Neuropathol 
Exp Neurol 2014;73:994-8.

55. Libard S, Popova SN, Amini RM, Kärjä V, Pietiläinen T, Hämäläinen KM, Sundström C, Hesselager G, Bergqvist M, Ekman S, Zetterling M, Smits A, Nilsson P, Pfeifer S, de Ståhl TD, Enblad G, Ponten F, Alafuzoff I. Human cytomegalovirus tegument protein pp65 is detected in all intra- and extra-axial brain tumours independent of the tumour type or grade. PLoS One 2014;9:e108861.

56. Ahani N, Nikravesh A, Shirkoohi R, Karimi Arzenani M, Rokouei M, Eskandani MA. Detection of human cytomegalovirus in glioma tumor tissues. Comparative Clin Pathol 2014;23:1321-30.

57. Tang KW, Hellstrand K, Larsson E. Absence of cytomegalovirus in high-coverage DNA sequencing of human glioblastoma multiforme. Int $J$ Cancer 2015;136:977-81.

58. Wakefield A, Pignata A, Ghazi A, Ashoori A, Hegde M, Landi D, Gray T, Scheurer ME, Chintagumpala M, Adesina A, Gottschalk S, Hicks J, Powell SZ, Ahmed N. Is CMV a target in pediatric glioblastoma? Expression of CMV proteins, pp65 and IE1-72 and CMV nucleic acids in a cohort of pediatric glioblastoma patients. $J$ Neurooncol 2015;125:307-15.

59. Bianchi E, Roncarati P, Hougrand O, Guérin-El Khourouj V, Boreux R, Kroonen J, Martin D, Robe P, Rogister B, Delvenne P, Deprez M. Human cytomegalovirus and primary intracranial tumors: frequency of tumor infection and lack of correlation with systemic immune antiviral responses. Neuropathol Appl Neurobiol 2015;41:e29-40.

60. Shamran HA, Kadhim HS, Hussain AR, Kareem A, Taub DD, Price RL, Nagarkatti M, Nagarkatti PS, Singh UP. Detection of human cytomegalovirus in different histopathological types of glioma in Iraqi patients. Biomed Res Int 2015;2015:642652.

61. Lin CT, Leibovitch EC, Almira-Suarez MI, Jacobson S. Human herpesvirus multiplex ddPCR detection in brain tissue from lowand high-grade astrocytoma cases and controls. Infect Agent Cancer 2016;11:32.

62. Taha MS, Abdalhamid BA, El-Badawy SA, Sorour YM, Almsned FM, Al-Abbadi MA. Expression of cytomegalovirus in glioblastoma multiforme: myth or reality? Br J Neurosurg 2016;30:307-12.

63. Stangherlin LM, Castro FL, Medeiros RS, Guerra JM, Kimura LM, Shirata NK, Nonogaki S, Dos Santos CJ, Carlan Silva MC. Human cytomegalovirus DNA quantification and gene expression in gliomas of different grades. PLoS One 2016;11:e0159604.

64. Soderberg-Naucler C, Rahbar A, Stragliotto G. Survival in patients with glioblastoma receiving valganciclovir. $N$ Engl $J$ Med 2013;369:985-6.

65. Stragliotto G, Rahbar A, Solberg NW, Lilja A, Taher C, Orrego A, Bjurman B, Tammik C, Skarman P, Peredo I, Söderberg-Nauclér C. Effects of valganciclovir as an add-on therapy in patients with cytomegalovirus-positive glioblastoma: a randomized, double-blind, hypothesis-generating study. Int J Cancer 2013;133:1204-13.

66. Cobbs CS. Does valganciclovir have a role in glioblastoma therapy? Neuro Oncol 2014;16:330-1.

67. Peng C, Wang J, Tanksley JP, Mobley BC, Ayers GD, Moots PL, Clark SW. Valganciclovir and bevacizumab for recurrent glioblastoma: a single-institution experience. Mol Clin Oncol 2016;4:154-8.

68. Söderberg-Nauclér C, Johnsen JI. Cytomegalovirus in human brain tumors: role in pathogenesis and potential treatment options. World $J$ Exp Med 2015;5:1-10

69. Tseliou M, Al-Qahtani A, Alarifi S, Alkahtani SH, Stournaras C, Sourvinos G. The role of RhoA, RhoB and RhoC GTPases in cell morphology, proliferation and migration in human cytomegalovirus (HCMV) infected glioblastoma cells. Cell Physiol Biochem 2016;38:94-109.

70. Porter AP, Papaioannou A, Malliri A. Deregulation of Rho GTPases in cancer. Small GTPases 2016;7:123-38.

71. Orgaz JL, Herraiz C, Sanz-Moreno V. Rho GTPases modulate malignant transformation of tumor cells. Small GTPases 2014;5:e29019.

72. Mazieres J, Antonia T, Daste G, Muro-Cacho C, Berchery D, Tillement V, Pradines A, Sebti S, Favre G. Loss of RhoB expression in human lung cancer progression. Clin Cancer Res 2004;10:2742-50.

73. Ferguson SD, Srinivasan VM, Ghali MG, Heimberger AB. Cytomegalovirus-targeted immunotherapy and glioblastoma: hype or hope? Immunotherapy 2016;8:413-23.

74. Schaller TH, Sampson JH. Advances and challenges: dendritic cell vaccination strategies for glioblastoma. Expert Rev Vaccines 2017;16:27-36.

75. Nair SK, De Leon G, Boczkowski D, Schmittling R, Xie W, Staats J, Liu R, Johnson LA, Weinhold K, Archer GE, Sampson JH, Mitchell DA. Recognition and killing of autologous, primary glioblastoma tumor cells by human cytomegalovirus pp65-specific cytotoxic T cells. Clin Cancer Res 2014;20:2684-94.

76. University PS. A Phase I-II Study of Allogeneic CMV Specific Cytotoxic $\mathrm{T}$ Lymphocytes (CTL) for Patients With Refractory Glioblastoma Multiforme (GBM). In: ClinicalTrials.gov [Internet]. Bethesda (MD): National Library of Medicine (US); 2000. Available from: http://clinicaltrials.gov/show/NCT00990496 NLM Identifier: NCT00990496. [Last accessed on 2017 Feb 22]

77. Medicine BCo. Phase I/II Administration of CMV (Cytomegalovirus)Specific Cytotoxic T Cells in Patients With Glioblastoma Multiforme (COGLI). In: ClinicalTrials.gov [Internet]. Bethesda (MD): National Library of Medicine (US); 2000. Available from: http://clinicaltrials. gov/show/NCT01205334 NLM Identifier: NCT01205334. [Last accessed on $2017 \mathrm{Feb} 22]$

78. Florida Uo. Peptide Targets for Glioblastoma Against Novel Cytomegalovirus Antigens. In: ClinicalTrials.gov [Internet]. Bethesda (MD): National Library of Medicine (US); 2000. Available from: http://clinicaltrials.gov/show/NCT01854099 NLM Identifier: NCT01854099. [Last accessed on 2017 Feb 22]

79. Center MDAC. A Phase I/II Clinical Trial of Autologous Cytomegalovirus (CMV)-Specific Cytotoxic T Cells for Glioblastoma (GBM) Patients. In: ClinicalTrials.gov [Internet]. Bethesda (MD): National Library of Medicine (US); 2000. Available from: http://clinicaltrials.gov/show/NCT02661282 NLM Identifier: NCT02661282. [Last accessed on 2017 Feb 22]

80. Florida Uo. A Phase II Randomized, Blinded, and Placebo-controlled Trial of CMV RNA-Pulsed Dendritic Cells With Tetanus-Diphtheria Toxoid Vaccine in Patients With Newly-Diagnosed Glioblastoma. In: ClinicalTrials.gov [Internet]. Bethesda (MD): National Library of Medicine (US); 2000. Available from: http://clinicaltrials.gov/show/ NCT02465268 NLM Identifier: NCT02465268. [Last accessed on 2017 Feb 22]

81. Gary Archer DUMC. Peptide Targets for Glioblastoma Against Novel Cytomegalovirus Antigens. In: ClinicalTrials.gov [Internet]. Bethesda (MD): National Library of Medicine (US); 2000. Available from: http://clinicaltrials.gov/show/NCT02864368 NLM Identifier: NCT02864368. [Last accessed on 2017 Feb 22]

82. Gary Archer DUMC. Evaluation of Overcoming Limited Migration and Enhancing Cytomegalovirus-specific Dendritic Cell Vaccines With Adjuvant TEtanus Pre-conditioning in Patients With Newlydiagnosed Glioblastoma. In: ClinicalTrials.gov [Internet]. Bethesda (MD): National Library of Medicine (US); 2000. Available from: http://clinicaltrials.gov/show/NCT02366728 NLM Identifier: NCT02366728. [Last accessed on 2017 Feb 22]

83. Gary Archer DUMC. AVeRT: Anti-PD-1 Monoclonal Antibody (Nivolumab) in Combination With DC Vaccines for the Treatment of Recurrent Grade III and Grade IV Brain Tumors. In: ClinicalTrials. gov [Internet]. Bethesda (MD): National Library of Medicine (US); 2000. Available from: http://clinicaltrials.gov/show/NCT02529072 
NLM Identifier: NCT02529072. [Last accessed on 2017 Feb 22]

84. Medicine BCo. Administration of HER2 Chimeric Antigen Receptor Expressing CMV-Specific Cytotoxic T Cells Ins Patients With Glioblastoma Multiforme (HERT-GBM). In: ClinicalTrials.gov [Internet]. Bethesda (MD): National Library of Medicine (US); 2000. Available from: http://clinicaltrials.gov/show/NCT01109095 NLM Identifier: NCT01109095. [Last accessed on 2017 Feb 22]

85. John Sampson DUMC. REGULATory T-Cell Inhibition With Basiliximab (Simulect $\left.{ }^{\circledR}\right)$ During Recovery From Therapeutic Temozolomide-induced Lymphopenia During Antitumor Immunotherapy Targeted Against Cytomegalovirus in Patients With Newly-Diagnosed Glioblastoma Multiforme. In: ClinicalTrials.gov [Internet]. Bethesda (MD): National Library of Medicine (US); 2000. Available from: http://clinicaltrials.gov/show/NCT00626483 NLM Identifier: NCT00626483. [Last accessed on 2017 Feb 22]

86. John Sampson DUMC. Anti-Tumor Immunotherapy Targeted Against Cytomegalovirus in Patients With Newly-Diagnosed Glioblastoma Multiforme During Recovery From Therapeutic Temozolomideinduced Lymphopenia. In: ClinicalTrials.gov [Internet]. Bethesda (MD): National Library of Medicine (US); 2000. Available from: http://clinicaltrials.gov/show/NCT00639639 NLM Identifier: NCT00639639. [Last accessed on 2017 Feb 22]

87. John Sampson DUMC. Evaluation of Recovery From Drug-Induced
Lymphopenia Using Cytomegalovirus-specific T-cell Adoptive Transfer. In: ClinicalTrials.gov [Internet]. Bethesda (MD): National Library of Medicine (US); 2000. Available from: http://clinicaltrials. gov/show/NCT00693095 NLM Identifier: NCT00693095. [Last accessed on 2017 Feb 22]

88. Hospital KU. A Randomized Double Blind Controlled Proof of Concept Study of the Efficacy and Safety of Valcyte ${ }^{\circledR}$ as an Add-on Therapy in Patients With Malignant Glioblastoma With Successful Surgical Resection of at Least $90 \%$ of the Initial Tumor and CMV Infection Demonstrated Histologically and Immunohistochemically. In: ClinicalTrials.gov [Internet]. Bethesda (MD): National Library of Medicine (US); 2000. Available from: http://clinicaltrials.gov/show/ NCT00400322 NLM Identifier: NCT00400322. [Last accessed on $2017 \mathrm{Feb} 22]$

89. Wick W, Wick A, Platten M. Good maths is needed to understand CMV data in glioblastoma. Int J Cancer 2014;134:2991-2.

90. Mitchell DA, Batich KA, Gunn MD, Huang MN, Sanchez-Perez L, Nair SK, Congdon KL, Reap EA, Archer GE, Desjardins A, Friedman AH, Friedman HS, Herndon JE 2nd, Coan A, McLendon RE, Reardon DA, Vredenburgh JJ, Bigner DD, Sampson JH. Tetanus toxoid and CCL3 improve DC vaccines in mice and glioblastoma patients. Nature 2015;519:366-9. 